\title{
Identification and Quantification of the Active Sites for Hydrogen Evolution on MoS2 Nanoparticles.
}

Bonde, Jacob Lindner; Jaramillo, Thomas; Jørgensen, Kristina Pilt; Horch, Sebastian; Nielsen, Jane Hvolbæk; Chorkendorff, lb

Published in:

Meeting Abstracts - Electrochemical Society

Publication date:

2007

Document Version

Publisher's PDF, also known as Version of record

Link back to DTU Orbit

Citation $(A P A)$ :

Bonde, J. L., Jaramillo, T., Jørgensen, K. P., Horch, S., Nielsen, J. H., \& Chorkendorff, I. (2007). Identification and Quantification of the Active Sites for Hydrogen Evolution on MoS2 Nanoparticles. In Meeting Abstracts Electrochemical Society (pp. Abstract 88). The Electrochemical Society.

\section{General rights}

Copyright and moral rights for the publications made accessible in the public portal are retained by the authors and/or other copyright owners and it is a condition of accessing publications that users recognise and abide by the legal requirements associated with these rights.

- Users may download and print one copy of any publication from the public portal for the purpose of private study or research.

- You may not further distribute the material or use it for any profit-making activity or commercial gain

- You may freely distribute the URL identifying the publication in the public portal 
Identification and Quantification of the Active Sites for Hydrogen Evolution on $\mathrm{MoS}_{2}$ Nanoparticles.

Jacob Bonde ${ }^{1}$, Thomas F. Jaramillo ${ }^{1}$, Kristina P. Jørgensen ${ }^{1}$, Jane H. Nielsen ${ }^{1}$, Sebastian Horch $^{2}$, Ib Chorkendorff ${ }^{1}$

${ }^{1}$ Center for Individual Nanoparticle Functionality, CINF

${ }^{2}$ Center for Atomic-scale Materials Design, CAMD Nano·DTU,

Department of Physics, Building 312 and 307, Technical University of Denmark, DK-2800 Lyngby, Denmark

A possible future energy carrier under consideration is $\mathrm{H}_{2}$, which can be produced cleanly and renewably if solar or wind energy is coupled to water electrolysis. Unfortunately, the Hydrogen Evolution Reaction (HER) is catalyzed most effectively by the $\mathrm{Pt}$ group metals - materials that are expensive and scarce. New materials are needed if this scheme is to ever become viable.

It has recently been proposed that the activity of HER electrocatalysts is governed by a simple descriptor: the free energy of hydrogen adsorption $\left(\Delta \mathrm{G}_{\mathrm{H}}\right)$. The activity follows the Sabatier principle with high catalytic activity at $\Delta \mathrm{G}_{\mathrm{H}} \approx 0[1]$. The predictor can be calculated by Density Functional Theory (DFT), which opens new possibilities in terms of finding alternative HER catalysts [2].

Another system where the free energy of hydrogen adsorption $\Delta \mathrm{G}_{\mathrm{H}}$ is close to zero is nanoparticulate $\mathrm{MoS}_{2}$. The active sites of $\mathrm{MoS}_{2}$ are solid state analogs to the active sites on hydrogen evolving enzymes like hydrogenase. Preliminary results showed that hydrogen in fact was evolved on graphite supported nanoparticulate $\mathrm{MoS}_{2}$ at a low overpotential [3].
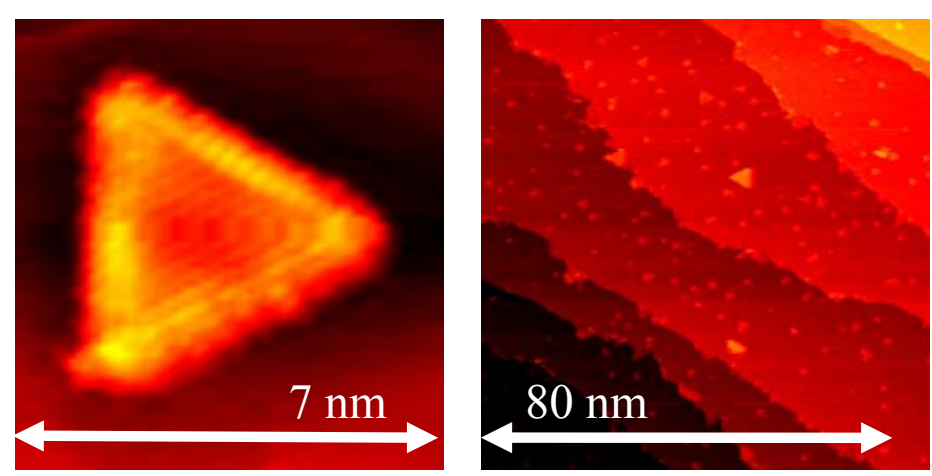

Figure 1. STM images of $\mathrm{MoS}_{2}$ particles on $\mathrm{Au}(111)$.

In order to investigate the $\mathrm{MoS}_{2}$ in more detail we have measured activity for the HER of UHV prepared and atomically imaged (with a scanning tunnelling microscope) $\mathrm{MoS}_{2}$ nanoparticles on $\mathrm{Au}(111)$. This made it possible to quantify the distribution of different sites present on the samples and compare that with the HER activity. On the $\mathrm{MoS}_{2}$ model system (see Figure 1) there generally exists two different sites the terrace site and the edge site(predicted to be active for HER in [3]). Measurements of the HER on samples with different coverage and particle size showed that the activity only correlated with the edge length of the particles. Thus we conclude that the edge indeed is the active site for HER on nanoparticulate $\mathrm{MoS}_{2}$, this also allows us to compare the activity of $\mathrm{MoS}_{2}$ to that of the pure metals plotted on the volcano in [1] and we find that the activity is below that of the Pt group metals and above that of the more common metals.

Investigations of the graphite supported nanoparticlulate $\mathrm{MoS}_{2} / \mathrm{C}$ investigated in [3] were also conducted. It was found that an irreversible oxidation of the $\mathrm{MoS}_{2} / \mathrm{C}$ takes place at anodic potentials (approx. 0.8 $\mathrm{V}$ vs. NHE). This oxidation severely inhibited the activity of the active sites for HER on the $\mathrm{MoS}_{2} / \mathrm{C}$.

The irreversible oxidation shows up as a welldefined peak in the cyclic voltammogram and we were able to use this peak to quantify the amount of $\mathrm{MoS}_{2} / \mathrm{C}$ present on the sample. Activity per site of $\mathrm{MoS}_{2} / \mathrm{C}$ was then compared to that of $\mathrm{MoS}_{2}$ on $\mathrm{Au}(111)$, preliminary results show that these activities are indeed comparable.

We have established that the irreversible oxidation method can be used to quantify the amount of nanoparticulate supported $\mathrm{MoS}_{2}$. Results on other metal sulfides will also be presented.

\section{References}

[1] J.K. Nørskov, T. Bligaard, A. Logadottir, J.R. Kitchin, J.G. Chen, S. Pandelov, U. Stimming,

"Trends in the Exchange Current for Hydrogen Evolution” J. Electrochem. Soc. (152), J23 (2005).

[2] J. Greeley, T. F. Jaramillo, J. Bonde, I. Chorkendorff, and J. K. Nørskov, "Computational High-Throughput Screening of Electrocatalytic Materials for Hydrogen Evolution" Nature Materials, (11) 909-913(2006).

[3] B. Hinnemann, P. G. Moses, J. Bonde, K. P. Jørgensen, J. H. Larsen, S. Horch, I. Chorkendorff, J.K. Nørskov, "Biomimetic Hydrogen Evolution”, J. Am. Chem. Soc., (127) 5308-5309 (2005). 